\title{
Grafting Fraser Fir (Abies fraseri): Effect of Scion Origin (Crown Position and Branch Order)
}

\author{
Haley Hibbert-Frey ${ }^{1}$, John Frampton ${ }^{2}$, Frank A. Blazich ${ }^{3}$, \\ Doug Hundley ${ }^{4}$, and L. Eric Hinesley ${ }^{3,5}$ \\ Department of Forestry and Environmental Resources, North Carolina State \\ University, Raleigh, NC 27695-8008
}

Additional index words. cleft graft, orthotropic growth, plagiotropism, topophysis, vegetative propagation, Christmas trees

\begin{abstract}
Success and subsequent growth of fraser fir [Abies fraseri (Pursh) Poir.] cleft grafts were studied in relation to origin and type of scion material in the tree crown. Firstand second-order shoots (current-year) were collected from five zones in the crown, ranging from top to bottom, and grafted to 5-year-old fraser fir transplants in April. Success rates were similar for first- and second-order scions, whereas budbreak and subsequent growth were best for first-order scions. In general, results were best for firstorder scions taken from the upper crown. Plagiotropism of grafts was similar for all crown zones and shoot types.
\end{abstract}

Fraser fir (Abies fraseri) is one of the most popular Christmas tree species in the United States. It occurs naturally at elevations above $1370 \mathrm{~m}$ on isolated mountaintops in the southern Appalachian Mountains from southwest Virginia through western North Carolina and into eastern Tennessee (Liu, 1971). It is grown commercially as a Christmas tree because of its pleasant fragrance, dark green foliage, natural conical shape, and strong branches (Frampton, 2001). In addition, it has good postharvest keepability (Hinesley and Chastagner, 2002). North Carolina has more than 1500 Christmas tree growers and 12,000 ha in production (North Carolina Department of Agriculture and Consumer Services, 2004) with fraser fir representing more than $95 \%$ of production. The farm-gate value of Christmas trees in North Carolina was $\approx \$ 134$ million in 2006 (U.S. Department of Agriculture, Economic Research Services, 2007).

Received for publication 23 Aug. 2010. Accepted for publication 10 Nov. 2010.

This research was funded in part by the North Carolina Agricultural Research Service (NCARS), Raleigh, NC 27695-7643, through the Christmas Tree Genetics Program.

Use of trade names in this publication does not imply endorsement by the NCARS of products named nor criticism of similar ones not mentioned. We thank Avery County Christmas tree grower, Herbie Johnson, for use of his land and Christmas trees and Fikret Isik for statistical assistance. This research is from a MS Thesis by the senior author. ${ }^{1}$ Former Graduate Research Assistant; currently: Live Care Curator, Discovery Place, 301 North Tryon Street, Charlotte, NC 28202.

${ }^{2}$ Professor.

${ }^{3}$ Professor, Department of Horticultural Science. ${ }^{4}$ IPM Technician, Avery County Extension Service, Newland, NC 28657.

${ }^{5}$ To whom reprint requests should be addressed; e-mail eric_hinesley@ncsu.edu.
Fraser fir normally is propagated by seed, but there is also interest in grafting it onto rootstocks of other Abies Mill. (fir) sp. with more resistance to phytophthora root rot (Phytophthora cinnamomi Rands) (Hinesley and Frampton, 2002). Resistant fir species might help reclaim infested land previously abandoned for Christmas tree production. Grafting also provides an opportunity to clonally propagate trees with desirable Christmas tree phenotypes.

During the 1980s, the North Carolina Division of Forest Resources used grafting to establish the first clonal seed orchard of fraser fir near Crossnore, NC. Subsequently, grafting has been used to establish several other seed orchards and clone banks of fraser fir. Despite this history, there is little published information for grafting fraser fir. Traditionally, it is grafted in March or April when stock plants are dormant, a busy season for Christmas tree growers. Efforts to identify alternative grafting dates have been unsuccessful (Hibbert-Frey et al., 2010).

Origin of scion material within the tree crown might affect graft success. Owing to correlative inhibition and differences in vigor, shoots produced in the same year decrease in length and diameter downward and inward within the crown (Kozlowski, 1964; Little, 1970; Wilson, 2000). In contrast, entire branches increase in age, length, and diameter from top to bottom of the tree. In vegetative propagation studies, stem cuttings of higher order often root in greater percentages than those of lower order (Copes, 1992; Garlo, 1980), but this generalization is not universal (Copes, 1987). Growth after rooting is usually best for first-order shoots because they initially have greater caliper and larger buds (Kozlowski, 1973; Little, 1970). In general, rooting capacity of fraser fir stem cuttings decreases with age of the ortet (Hinesley and Blazich, 1980; Rosier et al., 2005) and is best for cuttings collected lower in the crown (Rosier et al., 2005). However, Garlo (1980) found no significant difference in rooting of second-order stem cuttings from the upper and lower crown of 24-year-old fraser fir in a seed orchard at Crossnore, NC.

Comparisons such as rooting capacity of cuttings from the upper versus lower crown, and first-order versus second-order cuttings, relate to topophysis, the effect of the position of the propagule in the source plant (ortet) on the growth and phenotype of progeny (ramets) (Hartmann et al., 2002). The same issues, but often less pronounced, are relevant for grafting. Because Christmas tree selections normally are made when trees are young, before the transition to the adult growth phase, grafts and rooted cuttings initially are not sexually mature so that all growth is vegetative.

Factors affecting rooting of fraser fir stem cuttings are well understood (Blazich and Hinesley, 1994), whereas factors affecting grafting success have received little attention. Garlo (1980) found no consistent relationship between rooting capacity and graft success for cuttings and scions from the upper and lower crowns. Traditionally, fraser fir is grafted using dormant scion material from the upper crown.

Plagiotropism - growth at an oblique angle to vertical - can reduce uniformity of rooted stem cuttings and grafted material and decreases overall shoot growth (Timmis et al., 1992). A plagiotropic plant has no vertical (orthotropic) leader; it continues growing like a branch. Abies sp. such as fraser fir are well known for plagiotropism after rooting of stem cuttings (Blazich and Hinesley, 1994). The time required for grafts to become orthotropic appears to decrease with increasing rootstock vigor at the time of grafting (Copes, 1980), but it might also be influenced by stock plant age, scion position in the ortet, and the propagation environment. If plagiotropism were similar for shoots from all parts of the crown, it would increase the availability of suitable scion material for grafting. Therefore, the objective of this study was to investigate success and growth of fraser fir grafts as affected by 1) scion origin in the crown (e.g., upper versus lower), and 2) branch order (first versus second).

\section{Methods and Materials}

In Sept. 2007, 100 fraser fir transplants (3 years grown in seedbed, 4 years grown in transplant bed $=7$ years from seed) growing under uniform fertility were selected for rootstocks in a nursery bed at a Christmas tree farm near Crossnore, $\mathrm{NC}$ (lat. $36^{\circ} 02^{\prime} \mathrm{N}$, long. $\left.81^{\circ} 93^{\prime} \mathrm{W}\right)$. At the same time, 10 fraser fir Christmas trees growing in an adjacent field for 8 years (13 years from seed; 2.1 to $2.4 \mathrm{~m}$ in height) were randomly selected for scion material. These trees were not sheared in 2007.

Scions (current-year shoots) were collected 18 Apr. 2008 from five zones in the crown, starting from the top and progressing downward: 1, upper crown; 2, upper midcrown; 3 , midcrown; 4, lower midcrown; and 5 , lowest portion of the crown (Fig. 1A). Because source trees were not sheared in 
2007, each scion had the terminal bud cluster intact. Average length of scions was $10 \mathrm{~cm}$, and caliper varied from 2 to $10 \mathrm{~mm}$ depending on the height and branch order. Two scions of each type (first- and second-order) were collected from each height zone within each sample tree. This provided scion material for 100 grafts (two grafters $\times$ two branch orders $\times$ five trees $\times$ five height zones). Scions were placed in pre-labeled bags, stored on ice, and grafted the same day.

True first- and second-order shoots were collected in height zones 2, 3, 4, and 5. Firstorder scions (secondary axes) were the distal shoots on nonsheared branches intersecting the shearing line of the tree (Fig. 1C). Secondorder scions were small shoots (tertiary axes) emerging from the node at the base (proximal end) of each first-order shoot.
Scions in the upper crown (Height 1) were collected from the first internode (Fig. 1B). First-order scions were the largest (greatest length and caliper), most vigorous currentyear lateral shoots (secondary axes) at the upper (distal) end of the internode, just below the node at the base of the current-year leader (primary axis). Additional scions (secondary axes), which were smaller (shorter and smaller caliper) and oriented more horizontally, were collected lower on the first internode. Because there were no true second-order shoots on the first internode, these smaller shoots were designated "second-order" to keep the treatments balanced.

Grafting was divided equally between two people. One person had 5 years of grafting experience; the other had 1 year of experience. Scions were grafted to rootstocks using a cleft
(A)

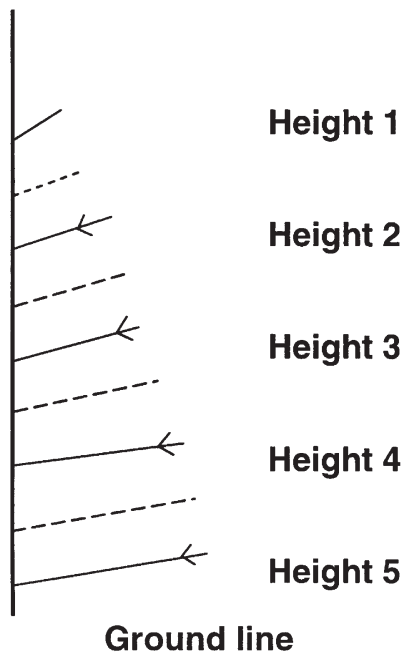

(B)

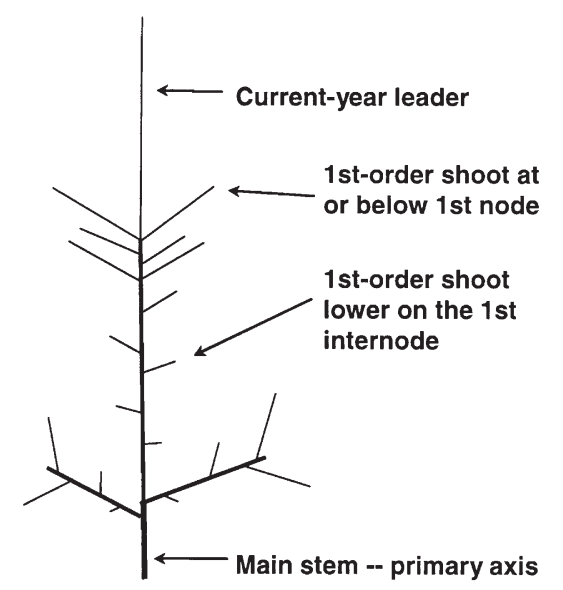

graft (Hinesley and Frampton, 2002). Usually, the scion was smaller in diameter than the rootstock, so the cambia of the rootstock and the scion were aligned on one side. There can be differences in opinion with respect to grafting terminology (cleft versus wedge), but there is precedent for calling this procedure cleft grafting (Copes, 1980; Garner, 1979; Hinesley and Frampton, 2002). After severing a leader (full length $=25$ to $40 \mathrm{~cm}$ ) at approximately half length, a prepared scion was inserted into a vertical cut in the leader stub. Grafts were wrapped with grafting rubbers $(20 \times 1 \mathrm{~cm})$ and sealed with Doc Farwell's Grafting Seal (Farwell Products, LLC, Wenatchee, WA). Aside from irrigation, transplants received no additional aftercare, e.g., shading, after grafting.

Grafts were evaluated 2 Aug. 2008, one growing season after grafting. For successful grafts, scion leader elongation, number of buds broken on the scion, lateral elongation, number of lateral buds on the shoot (leader), and number of lateral buds per decimeter were recorded. In addition, grafts were classified as plagiotropic or not plagiotropic (Fig. 2).

The experiment was a completely randomized design. Data were analyzed using Proc GLM and Proc GENMOD (SAS Institute, Inc., 2003) and all variables were considered fixed effects. An analysis of variance (ANOVA) was conducted to test for differences among main effects (grafter, height, branch order) and interactions (height $x$ branch order) for leader elongation, number of terminal buds broken, longest lateral length, number of lateral buds on the leader, and number of lateral buds per decimeter $(P \leq 0.05)$. Least squared means were used for comparisons.

For binomial response variables (graft success and scion plagiotropism), a generalized linear model with a logistic link function was performed with Proc GenMod using the same classification variables used in the ANOVA for continuous variables. It was necessary to omit the "height $\times$ order" interaction from the model to achieve convergence for the latter two response variables. Type III likelihood ratio statistics were used to evaluate differences. When detected, a Wald chi-square test was used to separate least squares means.

\section{Results}

Grafter 1 ( 5 years experience) had a success rate of $86 \%$ compared with $54 \%$ for Grafter 2 (1 year of experience) ( $P \leq$ 0.05 ; Table 1). Scions from the upper crown (Height 1) had a higher success rate $(90 \%$ versus $50 \%$ to $70 \%$ ), more complete budbreak, and greater shoot elongation and lateral bud density than scions from lower in the crown (Height 2 through 5) (Table 2). Budbreak, shoot elongation, and lateral bud density after grafting were similar for scions from height sectors 2 through 5 (Table 2) but less than for the upper crown. First-order and second-order scions had similar graft success, but first-order scions were superior 


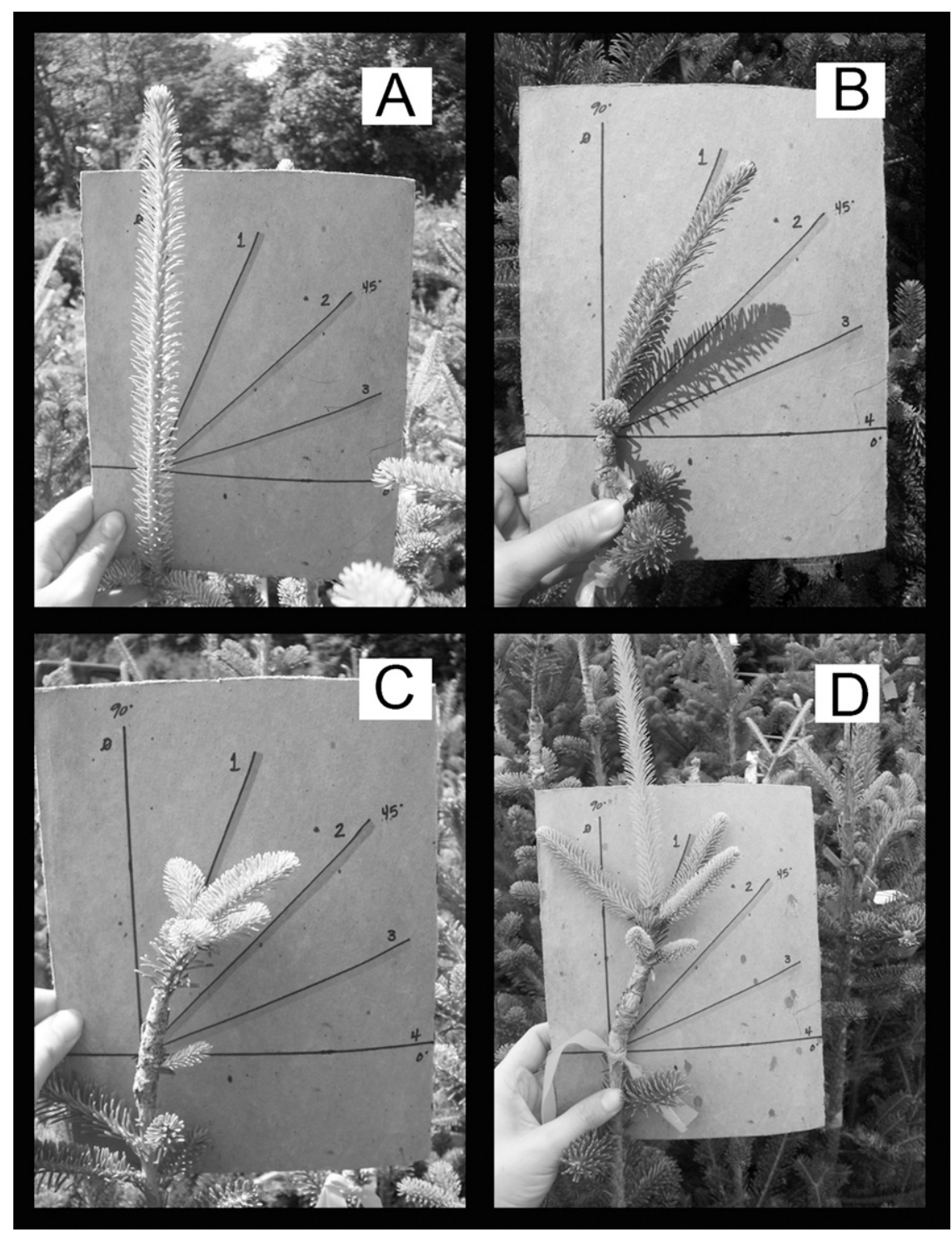

Fig. 2. Plagiotropism of fraser fir grafts made Apr. 2008. (A) Orthotropic growth of scion; (B) Scion plagiotropism; (C) Graft union plagiotropism; and (D) Orthotropic growth of scion from a plagiotropic graft union.

Table 1. Analysis of variance of binomial and continuous variables for fraser fir grafts made Apr. 2008 near Crossnore, NC.

\begin{tabular}{|c|c|c|c|c|c|c|c|c|c|}
\hline \multirow[b]{3}{*}{ Source ${ }^{z}$} & \multirow[b]{3}{*}{ df } & \multicolumn{3}{|c|}{ Binomial variables } & \multicolumn{5}{|c|}{ Continous variables } \\
\hline & & \multirow[b]{2}{*}{ Success } & \multicolumn{2}{|c|}{ Plagiotropism } & \multirow{2}{*}{$\begin{array}{l}\text { Leader } \\
\text { length }\end{array}$} & \multirow{2}{*}{$\begin{array}{l}\text { No. buds } \\
\text { broken }\end{array}$} & \multirow{2}{*}{$\begin{array}{l}\text { Lateral } \\
\text { length }\end{array}$} & \multirow{2}{*}{$\begin{array}{l}\text { No. lateral } \\
\text { buds }\end{array}$} & \multirow{2}{*}{$\begin{array}{l}\text { No. lateral } \\
\text { buds/length }\end{array}$} \\
\hline & & & Scion & Graft union & & & & & \\
\hline Grafter & 1 & $*$ & NS & NS & NS & NS & NS & NS & NS \\
\hline Tree (grafter) & 8 & $*$ & NS & NS & NS & $*$ & $*$ & $*$ & $*$ \\
\hline Height & 4 & $*$ & NS & NS & $*$ & $*$ & $*$ & $*$ & $*$ \\
\hline Orderw & 1 & NS & NS & NS & $*$ & $*$ & $*$ & $*$ & $*$ \\
\hline Height $\times$ order & 4 & NS & NS & NS & NS & $*$ & NS & NS & NS \\
\hline
\end{tabular}

zThere was a total of 100 grafts made in April, 50 by each of two grafters.

${ }^{\mathrm{y}}$ Longest lateral bud elongation.

${ }^{x}$ Number of newly formed lateral buds along the leader by decimeter.

${ }^{\mathrm{w}}$ Lateral branch order (first or second).

Ns, * Nonsignificant or significant at $P \leq 0.05$, respectively.

in shoot elongation and budset after grafting (Table 2).

Eighty-one percent of the grafts exhibited some degree of plagiotropism (Fig. 2) after the first growing season (data not presented), but there were no differences attributable to crown order shoots consistently broke more terminal buds, especially in the upper middle crown (Height 2) (Fig. 3).

\section{Discussion}

Origin of scions in the ortet influenced graft success but did not affect plagiotropism after grafting (Table 1). Scions from the upper crown had the highest graft success, greatest elongation of leaders and laterals, most terminal buds broken, most new laterals formed on the leader, and the most laterals per unit length of the leader (Table 2). Clearly, the upper crown (Height 1) was the best position to collect scion material from 2-m-tall fraser fir Christmas trees. Scions from the other crown sectors (Height 2 to Height 5), although not as good as those from the upper crown (Height 1), yielded a success rate of $50 \%$ to $70 \%$, (Table 2), sufficient to justify their use in grafting. This would increase the number of usable scions from a selected ortet

First-order scions yielded leader and lateral elongation almost two times greater than second-order scions (Table 2). First-order shoots also formed five times more lateral buds on the leader. Thus, the most distal shoot (first-order) on a branch (regardless of height origin) has a greater possibility of producing a successful graft with preferred growth and structure than a second-order shoot on the same branch. This likely reflects differences in vigor; first-order shoots have larger and more numerous buds and greater potential growth than second-order shoots.

Lateral shoots of many conifers, especially Abies and Picea A. Dietr. (spruce) sp., tend to remain plagiotropic for some time after rooting. This is usually a temporary condition. Some workers believe there is a branch "memory" from the original orientation of douglasfir scions (Timmis et al., 1992). In the present investigation, the development of plagiotropism in grafted scions possibly resulted from formation of more xylem and compression wood on the adaxial (top) side of the bending stems as a response to gravitational disorientation to reposition the branches to an equalized position, as occurs in rooted stem cuttings of fraser fir (Wise et al., 1986). Garlo (1980) observed minimal incidence and duration of plagiotropism for fraser fir grafts with a welldeveloped union. When orthotropic shoots of 4-year-old fraser fir seedlings were grafted to seedling rootstocks of fraser fir, $97 \%$ were orthotropic after the first growing season (Hinesley and Frampton, 2002). In another experiment, 600 first-order scions of fraser fir were grafted to 6-year-old fraser fir (1 year in the field, 0.6 to $0.8 \mathrm{~m}$ tall), and most leaders were orthotropic 2 years after grafting (Hinesley and Frampton, unpublished data). In our experience with grafting fraser fir, scions often display some plagiotropism the first season but become orthotropic the next year. Weak growth after grafting and failure to become orthotropic often result from a poor union between the scion and rootstock. In those situations, a branch or 
Table 2. Significant least square mean values for success rates and growth traits of fraser fir grafts made Apr. 2008 near Crossnore, NC.

\begin{tabular}{|c|c|c|c|c|c|c|c|c|c|}
\hline \multirow[b]{2}{*}{ Traits } & \multirow[b]{2}{*}{ Grafter } & \multirow{2}{*}{$\frac{\text { Tree }}{(\text { range })^{y}}$} & \multicolumn{5}{|c|}{$\mathrm{Ht}^{\mathrm{z}}$} & \multicolumn{2}{|c|}{ Order } \\
\hline & & & 1 & 2 & 3 & 4 & 5 & 1 & 2 \\
\hline Success $(\%)$ & $86^{x}, 54^{w}$ & $30-100$ & $90 \mathrm{a}$ & $70 \mathrm{~b}$ & $50 \mathrm{~b}$ & $70 \mathrm{~b}$ & $70 \mathrm{~b}$ & NS & \\
\hline Leader length (mm) & NS & NS & $125 \mathrm{a}$ & $40 \mathrm{~b}$ & $64 \mathrm{~b}$ & $48 \mathrm{~b}$ & $41 \mathrm{~b}$ & 83 & 45 \\
\hline Terminal buds broken (no.) & NS & $2.6-5.2$ & $5.3 \mathrm{a}$ & $3.4 \mathrm{~b}$ & $3.1 \mathrm{~b}$ & $3.4 \mathrm{~b}$ & $3.6 \mathrm{~b}$ & 4.3 & 3.2 \\
\hline$(\mathrm{mm})$ & NS & $0.4-2.1$ & $2.5 \mathrm{a}$ & $1.0 \mathrm{~b}$ & $1.8 \mathrm{ab}$ & $1.2 \mathrm{~b}$ & $1.1 \mathrm{~b}$ & 2.0 & 1.1 \\
\hline Lateral buds (no.) & NS & - & $3.8 \mathrm{a}$ & $0.5 \mathrm{~b}$ & $0.6 \mathrm{~b}$ & $0.4 \mathrm{~b}$ & $0.3 \mathrm{~b}$ & 1.9 & 0.4 \\
\hline Lateral buds/length (no./dm) & NS & - & $24 \mathrm{a}$ & $0.8 \mathrm{~b}$ & $0.5 \mathrm{~b}$ & $0.6 \mathrm{~b}$ & $0.5 \mathrm{~b}$ & 1.5 & 0.4 \\
\hline
\end{tabular}

${ }^{\mathrm{z}}$ Means within a row followed by the same letter are not significantly different at $P \leq 0.05$ according to Wald chi-square test.

${ }^{y}$ Tree-to-tree variation was not a main area of study.

${ }^{x}$ Success rate (\%) for Grafter 1.

${ }^{\text {w Success rate }(\%) \text { for Grafter } 2 .}$

NS $=$ Nonsignificant at $P \leq 0.05$.

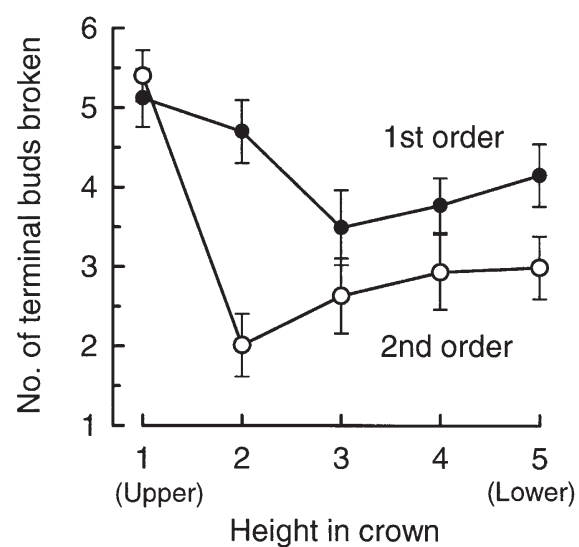

Fig. 3. "Height $\times$ branch order" interaction (mean number of terminal buds broken on the leader) for successful fraser fir grafts made Apr. 2008 in Crossnore, NC. Data points represent the mean \pm SE. Note: all scions in the upper crown (Height 1) were first-order; those designated as "second order" were smaller and lower on the top internode than those designated "first order" (Fig. 1B).

sprout below the graft frequently gains apical dominance and becomes the new leader (primary axis).

This study used fraser fir as scions and rootstocks. Fraser fir is still grafted to fraser fir on sites where phytophthora root rot is not a problem. Where root rot is a risk, or already present, momi fir (A. firma Sieb. \& Zucc.) or turkish fir (A. bornmuelleriana Mattf.) rootstocks are preferred owing to increased resistance (Benson et al., 1998). In earlier research, rootstocks of turkish fir yielded results (for graft success and growth) similar to fraser fir when grafted with fraser fir scions (Hinesley and Frampton, 2002). Later experience with momi fir has shown similar results. Thus, we believe results for scion/ rootstock combinations of fraser fir are indicative of results that would be obtained for scion/rootstock combinations of fraser fir with other fir species.

\section{Literature Cited}

Benson, D.M., L.E. Hinesley, J. Frampton, and K.C. Parker. 1998. Evaluation of six Abies spp. to phytophthora root rot caused by Phytophthora cinnamomi. Biological and Cultural Tests for Control of Plant Diseases 13:57.

Blazich, F.A. and L.E. Hinesley. 1994. Propagation of Fraser fir. J. Environ. Hort. 12:112-117.

Copes, D.L. 1980. Effect of rootstock vigor on leader elongation, branch growth, and plagiotropism in 4- and 8-year-old Douglas-fir grafts. Tree Planters' Notes 31:11-15.

Copes, D.L. 1987. Rooting sitka spruce from southeast Alaska. Pacific Northwest Forest and Range Expt. Sta., Res. Note PNW-RN-465.

Copes, D.L. 1992. Effects of long-term pruning, meristem origin, and branch order on the rooting of Douglas-fir stem cuttings. Can. J. For. Res. 22:1888-1894.

Frampton, J. 2001. North Carolina's Christmas tree genetics program. Proc. 26th Southern For. Tree Improvement Conf., Athens, GA, 26-29 June 2001.

Garlo, A. 1980. Vegetative propagation of Fraser fir seed orchard trees by rooted cuttings and grafting. MS Thesis, NC State Univ., Raleigh, NC.

Garner, R.J. 1979. The grafter's handbook. Oxford Univ. Press, New York, NY.
Hartmann, H.T., D.E. Kester, F.T. Davies, Jr., and R.L. Geneve. 2002. Hartmann and Kester's plant propagation: Principles and practices. 7th ed. Prentice Hall, Upper Saddle River, NJ.

Hibbert-Frey, H., J. Frampton, F.A. Blazich, and L.E. Hinesley. 2010. Grafting Fraser fir (Abies fraseri): Effect of grafting date, shade, and irrigation. HortScience 45:617-620.

Hinesley, E. and J. Frampton. 2002. Grafting Fraser fir onto rootstocks of selected Abies species. HortScience 37:815-818.

Hinesley, L.E. and F.A. Blazich. 1980. Vegetative propagation of Abies fraseri by stem cuttings. HortScience 15:96-97.

Hinesley, L.E. and G.A. Chastagner. 2002. Christmas tree keepability. In: Gross, K.C., C.Y. Wang, and M. Saltveit (eds.). The commercial storage of fruits, vegetables, and florist and nursery crops. Draft revision of Agric. Hdbk. 66. U. S. Dept. Agr., Agricultural Res. Serv., Beltsville, MD. 20 Oct. 2009. <http//www.ba.ars.usda.gov/hb66/ index.html $>$.

Kozlowski, T.T. 1964. Shoot growth in woody plants. Bot. Rev. 30:335-392.

Kozlowski, T.T. 1973. Predictability of shoot length from bud size in Pinus resinosa Ait. Can. J. For. Res. 3:34-38.

Little, C.H.A. 1970. Apical dominance in long shoots of white pine (Pinus strobus). Can. J. Bot. 48:239-253.

Liu, T.-S. 1971. A monograph of the genus Abies. Dept. For., College Agr., Natl. Taiwan Univ., Taipei, Taiwan (Republic of China).

North Carolina Department of Agriculture and Consumer Services. 2004. NC Christmas tree facts. 15 Oct. 2008. <http://www.ncagr.gov/ markets/commodit/horticul/xmastree/>.

Rosier, C.L., J. Frampton, B. Goldfarb, F.C. Wise, and F.A. Blazich. 2005. Stumping height, crown position, and age of parent tree influence rooting of stem cuttings of Fraser fir. HortScience 40:771-777.

SAS Institute, Inc. 2003. SAS OnlineDoc ${ }^{\circledR}$, Version 9. SAS Inst., Inc., Cary, NC.

Timmis, R., G.A. Ritchie, and G.S. Pullman. 1992. Age- and position-of-origin and rootstock effects in Douglas-fir plantlet growth and plagiotropism. Plant Cell, Tissue Organ Cult. 29:179186.

U.S. Department of Agriculture, Economic Research Services. 2007. Amber waves-Did you know? Bul. 19 Oct. 2009. <http://www.ers.usda.gov/ AmberWaves/November07/PDF/DidYouKnow. pdf>.

Wilson, B.F. 2000. Apical control of branch growth and angle in woody plants. Amer. J. Bot. 87: 601-607.

Wise, F.C., F.A. Blazich, and L.E. Hinesley. 1986. Reduction of initial plagiotropic growth of softwood Fraser fir cuttings. J. Amer. Soc. Hort. Sci. 111:21-26. 